\title{
Experience of an online course on sexuality during pregnancy for residents
}

\author{
Teresa Cristina Souza Barroso Vieira ${ }^{a}$, Mary Uchiyama Nakamura ${ }^{\text {, }}$ Ivaldo da Silva ${ }^{\mathrm{b}}$, \\ Maria Regina Torloni ${ }^{\mathrm{a}, \mathrm{c}, *}$, Meireluci Costa Ribeiro ${ }^{\text {a }}$, Marco de Tubino Scanavino ${ }^{\mathrm{d}}$, Eduardo de Souza ${ }^{\mathrm{a}}$ \\ a Department of Obstetrics, São Paulo Federal University (UNIFESP), Rua Napoleão de Barros, 875, Vila Clamentino, CEP 04124-002 São Paulo, São Paulo, Brazil \\ ${ }^{\mathrm{b}}$ Department of Gynecology, São Paulo Federal University (UNIFESP), São Paulo, Brazil \\ ${ }^{\mathrm{c}}$ Department of Internal Medicine, São Paulo Federal University (UNIFESP), São Paulo, Brazil \\ ${ }^{\mathrm{d}}$ Department and Institute of Psychiatry, São Paulo State University Medical School (FMUSP), São Paulo, Brazil
}

\section{A R T I C L E I N F O}

\section{Article history:}

Received 26 October 2016

Revised 1 March 2017

Accepted 8 March 2017

\section{Keywords:}

Female sexual function

Medical education

Medical residency

Pregnancy

Sexology

Sexuality

\begin{abstract}
A B S T R A C T
Objective: Many obstetrics and gynecology (Ob/Gyn) residents report insufficient knowledge about female sexuality and this has a negative impact on their capacity to manage their patients. The aim of this study was to describe an online course about sexuality during pregnancy for Brazilian Ob/Gyn residents and evaluate their knowledge acquisition.

Methods: This longitudinal educational intervention study involved 219 Brazilian Ob/Gyn residents. The online course lasted $24 \mathrm{~h}$ (10 video lectures and discussion chats). Upon enrollment, the participants answered a questionnaire in regard to their training, attitudes and practices about sexuality during pregnancy. Participants' knowledge acquisition was assessed using a pre- and post-course test about sexuality during pregnancy. At the end of the course, participants were asked to evaluate their educational experience. Student's $t$ and chi-square tests were used to analyze the pre- and post-course test scores. $P$ values $<0.05$ were considered statistically significant.

Results: A total of $143 \mathrm{Ob} / \mathrm{Gyns}$ (65.3\% of those enrolled) completed the course. At baseline, most participants reported that they did not have any sexology classes as undergraduates (62.5\%) or in their residency (52.1\%), and that they lacked specific knowledge in this area to manage their patients. Mean test scores increased significantly at the end of the course: $4.4( \pm 1.6)$ versus $6.0( \pm 1.3)$ (out of a maximum score of 10$)$, before and after the course, respectively $(p<0.0001)$. Most of the residents rated the overall quality of the course as "higher than expected".

Conclusion: An online course for Ob/Gyn residents was associated with a significant increase in knowledge about sexuality during pregnancy.
\end{abstract}

(C) 2017 Elsevier B.V. All rights reserved.

\section{Introduction}

The World Health Organization (WHO) defines sexual health as "the experience of the ongoing process of physical, psychological and socio-cultural wellbeing related to sexuality. It is not the merely the absence of dysfunction, disease and/or infirmity" [1]. In 2000, the Pan American Health Organization (PAHO) and the World Association for Sexual Health (WAS) recommended that in order to promote sexual health, it was important to provide education, training and support to professionals working in sexual health related fields [2].

* Corresponding author at: São Paulo Federal University, Rua Borges Lagoa, 564 cj 63, São Paulo 04038-000, Brazil.

E-mail address: ginecologia@terra.com.br (M.R. Torloni).
There are few sexual education programs specifically targeted at medical residents [3-5]. Yet, specific knowledge is needed in order to manage problems related to sexuality in different periods of life [6]. Pregnancy is a unique period in the lives of women and their partners when sexual dysfunction symptoms are very frequent [7-10]. Many studies report that pregnant women would like to receive more information about sexual issues during pregnancy from their health care providers [7,11-13]. However, obstetrics-gynecology (Ob/Gyn) residents often report that they lack knowledge in this area and feel insecure managing their patients' sexual complaints [14-17]. Residents would like to have more education in this area and have suggested that online modules could be useful to improve their knowledge and confidence to deal with sexual issues [14]. Based on a previous survey with Brazilian residents [16] we developed an online sexology course 
for Ob/Gyn residents to complement their training. We hypothesized that this online course would improve the participants' knowledge about sexuality during pregnancy.

This article presents the experience of Ob/Gyn residents in a developing country taking an online course on sexuality during pregnancy. The main study objective was to evaluate the knowledge acquisition of the participants. Secondary objectives were the assessment of the training attitudes and practices of the participants on sexuality during pregnancy at the onset of the course and their satisfaction with this educational experience at the end of it.

\section{Materials and methods}

This was a longitudinal, educational intervention study conducted in the city of São Paulo, Brazil in 2014. The study protocol was approved by the Ethics Committee of São Paulo Federal University, Process No. 05889712.0.0000.5505 (Sep 21st 2012). All of the participants gave their online informed consent when registering for the course.

Any medical doctors enrolled in officially accredited Ob/Gyn residency programs were eligible to participate.

The course, lasting a total of $24 \mathrm{~h}$, was divided into 10 online modules of $1 \mathrm{~h}$ and 40 min each (consisting of two 50 min lectures) and weekly discussion chats. A professional company was specifically hired to record the lectures at its studios and to create the course web platform. The course content included the history of sexuality, anatomy and physiology of human sexual response, male and female sexual dysfunctions during and after pregnancy, sexual history taking, and treatments of sexual dysfunctions (Table 1 ). The content of the online course was developed according to the recommendations of the Brazilian Federation of Obstetrics and Gynecologists. The lecturers were medical doctors (Ob/Gyn, urologists and psychiatrists), psychologists, social workers and physiotherapists specialized in sexology.

The principal investigator personally contacted each of the $\mathrm{Ob} /$ Gyn residency coordinators in the City of São Paulo, informed them about the course, and asked them to disseminate the information among their residents and to encourage them to enroll in the free online sexology course. Participants could enroll online, in a web-

Table 1

Program of the online sexology course for Ob/Gyn residents.

\begin{tabular}{|c|c|c|}
\hline Module & Lecture $\mathrm{A}$ (50 min) & Lecture $B(50 \mathrm{~min})$ \\
\hline Inaugural & $\begin{array}{l}\text { Course presentation and } \\
\text { course content }\end{array}$ & $\begin{array}{l}\text { Importance of human sexuality for } \\
\text { the Ob/Gyn specialist }\end{array}$ \\
\hline 1 & $\begin{array}{l}\text { History of sexuality } \\
\text { Anatomy of human sexual } \\
\text { response cycle }\end{array}$ & $\begin{array}{l}\text { Anatomic changes in pregnancy } \\
\text { and after childbirth (PC) }\end{array}$ \\
\hline 2 & $\begin{array}{l}\text { Physiology of male and } \\
\text { female sexual response }\end{array}$ & Sexual response during pregnancy \\
\hline 3 & $\begin{array}{l}\text { Treatment of sexual } \\
\text { disorders }\end{array}$ & $\begin{array}{l}\text { Treatment of sexual disorders in } \\
\text { PC } \\
\text { Sexual history taking }\end{array}$ \\
\hline 4 & $\begin{array}{l}\text { Female sexual dysfunctions } \\
\text { (FSD) }\end{array}$ & FSD symptoms in pregnancy \\
\hline 5 & Male sexual dysfunctions & $\begin{array}{l}\text { The impact of male sexual } \\
\text { dysfunctions on pregnant } \\
\text { woman's sexuality }\end{array}$ \\
\hline 6 & Psychotherapy & Psychotherapy in PC \\
\hline 7 & Pharmacotherapy & Pharmacotherapy in PC \\
\hline 8 & $\begin{array}{l}\text { The impact of gynecological } \\
\text { surgeries on female } \\
\text { sexuality }\end{array}$ & $\begin{array}{l}\text { The impact of gynecological } \\
\text { surgeries on female sexuality in } \\
\text { pregnancy }\end{array}$ \\
\hline 9 & $\begin{array}{l}\text { Ethical issues } \\
\text { Treatment of FSD }\end{array}$ & $\begin{array}{l}\text { Sexual education groups with } \\
\text { pregnant couples }\end{array}$ \\
\hline 10 & Clinical case studies & $\begin{array}{l}\text { Discussion of test questions and } \\
\text { course evaluation } \\
\text { Sexology in PC }\end{array}$ \\
\hline
\end{tabular}

site specifically created for this course during a period of seven months (March to September 2014).

Upon registration, the residents provided socio demographic and professional information (e.g. gender, age, year of residency and marital status) and filled an anonymous online questionnaire to assess their training about sexuality during medical school and residency, as well as their attitudes and practices related to sexuality during pregnancy. Before watching the first online video lecture, the residents had to answer the pre-course test (Test A) which contained 36 multiple-choice questions on human sexuality.

The weekly online modules were posted on a YouTube channel, private for only participants who were registered for the course, and could be assessed at any time (through individual student login) during a period of seven months (April 7 to September 30, 2014). Each Monday, a new video lecture was posted by the course organizers, along with topics for online discussion in the course chat room. The principal investigator checked the postings daily and was available throughout the course to give information, answer questions, and make comments. The last video was posted on June 9th 2015 as well as the post-course test (Test B) and a questionnaire to assess their satisfaction with the course.

After turning in the post-course test, the participants received an email with their scores in the pre- and post-course tests, the correct answers to both tests and a certificate of completion endorsed by São Paulo Federal University. The residency coordinators of each institution also received individual emails with the results of their residents' progress (pre- and post-course test scores) and their evaluation of the course. These data were deidentified so that the names of the individual residents did not appear on the resident coordinators' reports.

\section{Evaluation of outcomes}

To evaluate the participants' previous training, attitudes and practices regarding sexuality during pregnancy, an online questionnaire was used, based on a previous national survey involving Brazilian physicians [18].

Knowledge acquisition was evaluated using pre- (Test A) and post- (Test B) course tests about sexuality during pregnancy. Both tests consisted of 36 multiple- choice questions. Each lecturer was asked to provide 4 questions about their topic; the principal investigator used these questions to create the tests. The mean total score of each test was calculated by dividing the total number of questions (36) by 10 and multiplying the result by the number of correct questions. The total test score ranged from 0 to 10 , with higher scores indicating higher knowledge about sexuality during pregnancy. Test B consisted of the same 36 questions as Test A, but presented in a different order.

The residents' satisfaction was assessed by using 20 multiple choice questions divided into five domains: (1) tangibles: physical facilities, equipment and appearance of personnel, (2) reliability: ability to perform the promised service dependably and accurately, (3) responsiveness: willingness to help the students and provide prompt service, (4) assurance: the teachers' knowledge and courtesy and their ability to inspire trust and confidence, and (5) empathy: caring, attention the teachers provide the students. The residents rated each domain using a five-point Likert scale ranging from "much less than expected" ( 1 point) to "much higher than expected" ( 5 points). We added the scores of each domain to obtain a total final score, ranging from a minimum of 20 to a maximum of 100. A twenty-first question was added which was a general quality question. All the questions were based on the SERVQUAL, a multiple-item scale that measures consumer perceptions of service quality [19]. It was adapted to measure educational services [20] and had good internal consistency (Cronbach's alpha 0.942). 


\section{Statistical aspects}

Sample size was calculated by considering a before- and aftercourse learning evaluation, and by using Student's $t$-test. A test score standard deviation of approximately 3.15 and a 0.5 correlation between the results of the pre- and post-course tests and a 1 point increase in the final test was assumed. With $\alpha=0.05$ and $\beta=80 \%$, a total of 80 participants would be needed to detect this difference.

The Student's $t$ and chi-square tests were used to analyze the results of pre- and post-course test scores. Descriptive statistics were used for the participants' socio demographic and professional characteristics, their training, attitudes and practices, and their degree of satisfaction with the course. Cronbach's alpha was used to evaluate the internal consistency of the course satisfaction questionnaire. To indicate good internal consistency, a minimum of Cronbach's alpha of 0.7 had to be present.

InStat 3 software (Statistical Services Centre, University of Reading, Reading, UK) was used for statistical analyses.

\section{Results}

Sample

A total of 219 residents enrolled in the course: $162(74 \%)$ were from five Ob/Gyn residency programs in the City of São Paulo, while 57 (26\%) were from other Ob/Gyn residency programs outside of the city who had heard about the course and spontaneously requested to enroll. Approximately $18 \%(n=40)$ of the residents did not watch any of the modules and $16 \%(n=36)$ dropped out of the course between the 3rd and the 10th modules. A total of 143 residents (65.3\% of those who enrolled) completed all the course activities and took the final test (Fig. 1). The residents who dropped out of the course were significantly older and a larger proportion of them was in the last year of their residency than those who completed the course (Table 2). Most of the residents who completed the course were female (87.4\%) and in the first two years of residency (51.7\%) (Table 2 ).

\section{Training, attitudes and practices}

Over $60 \%$ of the enrolled participants reported having no previous training or classes about sexology during medical school, while $79 \%$ declared that they had received less than six hours of sexology training or no training during their residency up to that moment. About 51\% did not feel confident giving answers about sexuality during pregnancy and nearly $84 \%$ of them attributed this difficulty to a lack of specific knowledge on the topic. Over $55 \%$ of the participants declared that they never or rarely took a sexual history of obstetric patients, while $41 \%$ did not know what to do when faced with a sexual complaint from these patients (Table 3 ).

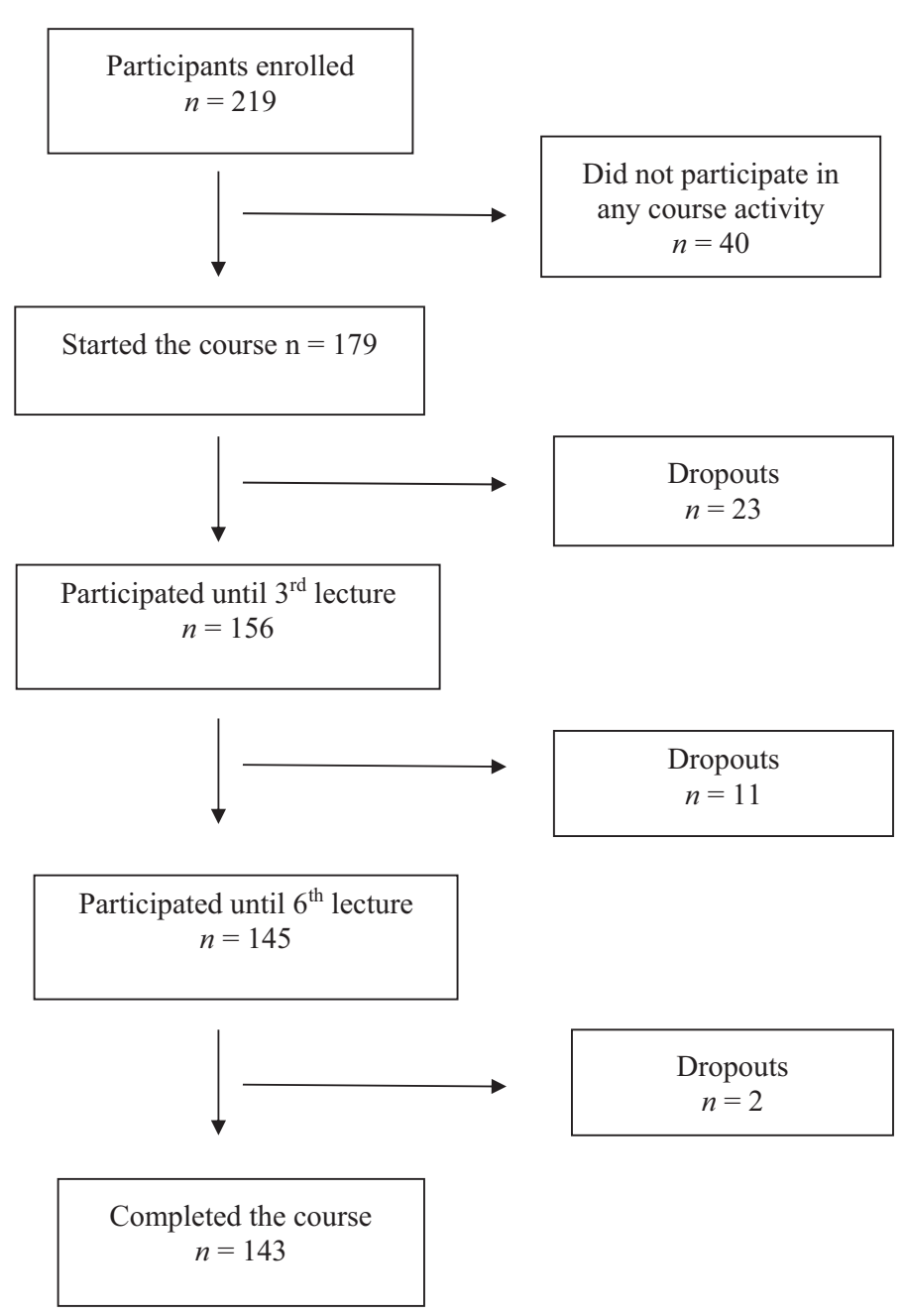

Fig. 1. Flow chart of course participants. 
Table 2

Characteristics of 219 Brazilian Ob/Gyn residents enrolled in an online sexology course on sexuality during pregnancy.

\begin{tabular}{|c|c|c|c|c|}
\hline & Registered $(\mathrm{n}=219)$ & Dropouts $(\mathrm{n}=76)$ & Completed the course $(n=143)$ & $p$ value \\
\hline Age, years & $28.0 \pm 2.1$ & $28.8 \pm 2.5$ & $27.9 \pm 2.1$ & $0.005^{\mathrm{b}}$ \\
\hline $\begin{array}{l}\text { Gender } \\
\text { Male } \\
\text { Female }\end{array}$ & $\begin{array}{l}31(14.2) \\
188(85.8)\end{array}$ & $\begin{array}{l}13(17.1) \\
63(82.9)\end{array}$ & $\begin{array}{l}18(12.6) \\
125(87.4)\end{array}$ & $0.42^{\mathrm{c}}$ \\
\hline $\begin{array}{l}\text { Residency y } \\
\text { R1-R2 } \\
\text { R3-R4 } \\
\text { R5-R6 }\end{array}$ & $\begin{array}{l}108(49.3) \\
84(38.4) \\
27(12.3)\end{array}$ & $\begin{array}{l}34(44.7) \\
26(34.2) \\
16(21.1)\end{array}$ & $\begin{array}{l}74(51.7) \\
58(40.6) \\
11(7.7)\end{array}$ & $0.02^{\mathrm{c}}$ \\
\hline
\end{tabular}

Values presented as mean \pm standard deviation or $\mathrm{N}(\%)$.

a Comparison between characteristics of dropouts versus residents who completed the course.

b Student's $t$ test.

c Chi-square test.

Table 3

Training, attitudes and practices of 219 Brazilian Ob/Gyn residents enrolled in an online sexology course.

\begin{tabular}{|c|c|c|}
\hline Question & $\mathrm{n}$ & $\%$ \\
\hline \multicolumn{3}{|l|}{ 1. Previous training or classes about sexuality during medical school } \\
\hline None & 137 & 62.6 \\
\hline$\leq 6 \mathrm{~h}$ & 62 & 28.3 \\
\hline$>6-10 \mathrm{~h}$ & 9 & 4.1 \\
\hline$>10 \mathrm{~h}$ & 11 & 5.0 \\
\hline \multicolumn{3}{|l|}{ 2. Previous training or classes about sexuality during $\mathrm{Ob} / \mathrm{Gyn}$ residency } \\
\hline None & 114 & 52.0 \\
\hline$\leq 6 \mathrm{~h}$ & 58 & 26.5 \\
\hline$>6-10 \mathrm{~h}$ & 19 & 8.7 \\
\hline$>10 \mathrm{~h}$ & 28 & 12.8 \\
\hline \multicolumn{3}{|c|}{$\begin{array}{l}\text { 3. Do you feel confident when you listen to questions and give answers to the } \\
\text { doubts that pregnant women have about sexual issues? }\end{array}$} \\
\hline No & 100 & 50.8 \\
\hline Yes, in part & 94 & 47.7 \\
\hline Yes, totally & 3 & 1.5 \\
\hline \multicolumn{3}{|l|}{$\begin{array}{l}\text { 4. If you have difficulty to deal with your obstetrics patients' sexual } \\
\text { complaints, this difficulty is due to: }\end{array}$} \\
\hline Lack of specific technical knowledge in this area & 165 & 83.7 \\
\hline Not enough time available during consultation & 14 & 7.1 \\
\hline Lack of effective treatments for these problems & 4 & 2.0 \\
\hline I don't have difficulties & 7 & 3.6 \\
\hline Other & 7 & 3.6 \\
\hline \multicolumn{3}{|c|}{$\begin{array}{l}\text { 5. Do you routinely take a sexual history or inquire about sexual complaints of } \\
\text { your obstetric patients, even when they don't spontaneously bring up } \\
\text { questions or complaints? }\end{array}$} \\
\hline Never & 34 & 17.2 \\
\hline Rarely & 76 & 38.6 \\
\hline Sometimes & 77 & 39.1 \\
\hline Frequently & 7 & 3.6 \\
\hline Always & 3 & 1.5 \\
\hline \multicolumn{3}{|c|}{$\begin{array}{l}\text { 6. What is your usual procedure when a pregnant patient voices a sexual } \\
\text { function complaint? }\end{array}$} \\
\hline I listen but I don't know what to do & 81 & 41.1 \\
\hline I listen and then offer counseling or guidance & 94 & 47.7 \\
\hline $\begin{array}{l}\text { I minimize the problem and say "don't worry, it's nothing" or } \\
\text { "things like that happen" }\end{array}$ & 14 & 7.1 \\
\hline Other & 8 & 4.1 \\
\hline
\end{tabular}

\section{Acquisition of knowledge}

The mean pre-course test score of the 143 participants who concluded the course was $4.4 \pm 1.5$ (range 0.3-6.7), compared to $6.0 \pm 1.3$ (range 1.4-8.3) in the post-course test $(p<0.0001)$.

\section{Satisfaction with the course}

All 143 participants agreed with the statement that the general quality of the course was "equal", "higher" or "much higher" than expected. Twenty-one participants (14.7\%) stated that they were dissatisfied with the interactions among the participants in the chat room. Most of the participants (65.2\%) graded the 20 items evaluated in the satisfaction questionnaire as "higher than expected" or "much higher than expected". Finally, $81.2 \%$ of the residents reported that they would recommend the course to a friend (Table 4).

\section{Discussion}

The majority of the $219 \mathrm{Ob} / \mathrm{Gyn}$ residents who participated in this study had little or no previous training about sexuality in medical school or in their residency program, yet the number of dropouts after enrollment was high (34.7\%). This is a common finding in online courses in health sciences and may be related to difficulties in organizing their time and having the necessary self-discipline to participate in this type of activity [21].

The main reason reported by the residents for enrolling in the course was their need to complement their very limited training in human sexuality during medical school and in their residency program. Similarly, 97\% of 154 Brazilian residents from different medical specialties (Ob/Gyn, psychiatry and internal medicine) reported that they wanted to have more sexual education activities to increase their knowledge on this topic [16]. The same lack of training about sexuality during medical school was reported by several other investigators from different countries [4,5,14,2224]. Although there are many publications on the subject that could help to fill this gap, lectures or courses about sexuality are often important in giving young physicians the initial motivation to embark on the journey of self-education. As stated by one of the residents who participated in our course: "During the course I bought several books recommended as additional reading by the lecturers and I am now fascinated with the topic. I am even planning to do a post-graduate [course] in this area!".

The findings from this study indicate that this online course for $\mathrm{Ob} /$ Gyn residents in Brazil was effective in increasing their knowledge acquisition about sexuality during pregnancy. The improvement in the participants' knowledge was consistent with other similar educational interventions. Yolsal et al. [4] reported that 163 Turkish residents from different programs had a significant increase in test scores at the end of a three- day ( $17 \mathrm{~h})$ presencial course about reproductive and sexual health and that the residents felt more prepared, motivated and confident to manage sexual issues with their patients. Similarly, other studies $[21,25]$ reported significant increases in participants' knowledge on other health topics upon completion of online courses.

Knowledge and skills are essential for physicians to feel confident and prepared to bring up and discuss sexuality and sexual issues with their patients. This is especially relevant for $\mathrm{Ob} / \mathrm{Gyns}$ 
Table 4

Level of satisfaction of 143 participants with an online course about sexuality during pregnancy.

\begin{tabular}{|c|c|c|c|c|c|}
\hline Question $^{a}$ & $\begin{array}{l}\text { Much lower than } \\
\text { expected } 1\end{array}$ & $\begin{array}{l}\text { Lower than } \\
\text { expected } 2\end{array}$ & $\begin{array}{l}\text { Within } \\
\text { expectations } 3\end{array}$ & $\begin{array}{l}\text { Higher than } \\
\text { expected } 4\end{array}$ & $\begin{array}{l}\text { Much higher than } \\
\text { expected } 5\end{array}$ \\
\hline \multicolumn{6}{|l|}{ Tangibles } \\
\hline 1. Clear and attractive homepages for student support & $1(0.7)$ & $6(4.2)$ & $50(35.0)$ & 58 (40.6). & $28(19.6)$ \\
\hline 2. Technological resources offered in the course & $1(0.7)$ & $9(6.3)$ & $77(53.8)$ & $38(26.6)$ & $18(12.6)$ \\
\hline $\begin{array}{l}\text { 3. Library collection compatible with the } \\
\text { requirements of the course }\end{array}$ & $1(0.7)$ & $4(2.8)$ & $57(39.9)$ & $44(30.8)$ & $37(25.9)$ \\
\hline \multicolumn{6}{|l|}{ Reliability } \\
\hline 4. Provision of the course as promised & $0(0.0)$ & $2(1.4)$ & 47 (32.9) & $53(37.1)$ & $41(28.7)$ \\
\hline 5. Provision of the modules according to schedule & $0(0.0)$ & $1(0.7)$ & $53(37.1)$ & $41(28.7)$ & $48(33.6)$ \\
\hline $\begin{array}{l}\text { 6. Usefulness of the course for professional } \\
\text { qualification }\end{array}$ & $0(0.0)$ & $4(2.8)$ & $38(26.6)$ & $64(44.8)$ & $37(25.9)$ \\
\hline 7. Teachers' capacity to answer students' questions & $2(1.4)$ & $2(1.4)$ & $58(40.6)$ & $47(32.9)$ & $34(23.8)$ \\
\hline 8. E-learning as an educational resource & $0(0.0)$ & $2(1.4)$ & $53(37.1)$ & $69(48.3)$ & $19(13.3)$ \\
\hline 9. Professional behavior of the teachers & $0(0.0)$ & $3(2.1)$ & $49(34.3)$ & $57(39.9)$ & $34(23.8)$ \\
\hline \multicolumn{6}{|l|}{ Responsiveness } \\
\hline 10. Solve students' doubts & $3(2.1)$ & $3(2.1)$ & $57(39.9)$ & $53(37.1)$ & $27(18.9)$ \\
\hline 11. Availability to attend students' needs & $2(1.4)$ & $0(0.0)$ & $16(11.2)$ & $56(39.2)$ & $69(48.3)$ \\
\hline $\begin{array}{l}\text { 12. Capacity to keep students well informed about the } \\
\text { course }\end{array}$ & $0(0.0)$ & $2(1.4)$ & $30(21.0)$ & $74(51.7)$ & $37(25.9)$ \\
\hline \multicolumn{6}{|l|}{ Assurance } \\
\hline 13. Teachers knowledgeable about topics presented & $0(0.0)$ & $0(0.0)$ & $33(23.1)$ & $58(40.6)$ & $52(36.4)$ \\
\hline 14. Teachers inspire confidence & $1(0.7)$ & $7(4.9)$ & $51(35.7)$ & $52(36.4)$ & $32(22.4)$ \\
\hline $\begin{array}{l}\text { 15. Teachers make students feel safe during the } \\
\text { classes }\end{array}$ & $0(0.0)$ & $4(2.8)$ & $62(43.4)$ & $50(35.0)$ & $27(18.9)$ \\
\hline \multicolumn{6}{|l|}{ Empathy } \\
\hline 16. Teachers that understand the students' need & $1(0.7)$ & $1(0.7)$ & $50(35.0)$ & $63(44.1)$ & $28(19.6)$ \\
\hline 17. Interaction between the participants & $2(1.4)$ & $19(13.3)$ & $68(47.6)$ & $36(25.2)$ & $18(12.6)$ \\
\hline \multicolumn{6}{|l|}{ Other } \\
\hline 18. The course met my expectations & $1(0.7)$ & $5(3.5)$ & $34(23.8)$ & $65(45.5)$ & $38(26.6)$ \\
\hline 19. The course helped me save time and money & $3(2.1)$ & $2(1.4)$ & $30(21.0)$ & $52(36.4)$ & $56(39.2)$ \\
\hline \multirow[t]{2}{*}{ 20. General quality of the course } & $0(0.0)$ & $0(0.0)$ & $10(7.0)$ & $80(55.9)$ & $53(37.1)$ \\
\hline & Certainly not 1 & No 2 & Not sure 3 & Yes 4 & Certainly yes 5 \\
\hline 21. Would you recommend the course to a friend? & $0(0.0)$ & $1(0.7)$ & $26(18.2)$ & $59(41.3)$ & $57(39.9)$ \\
\hline
\end{tabular}

Values presented as $\mathrm{N}(\%)$.

a Questionnaire based on the SERVQUAL [19]. Total score range from 20 to 100, with higher scores indicating better quality of the course.

residents since counseling about sexuality in pregnancy may improve the sexual quality of life of couples during this period $[9,26]$. Nevertheless, a recent Brazilian study involving 207 professors from 110 medical schools found that over 55\% of the respondents $(n=113)$ devoted only up to $6 \mathrm{~h}$ teaching sexual health topics and only $19 \%$ of them devoted $7-15 \mathrm{~h}$ to this subject in the medical school curriculum [22].

Although this model of an online course can increase the participants' theoretical knowledge about sexuality, it cannot substitute for the practical training that can only be acquired from supervised contact with patients during medical school or residency [5,27]. According to Parish and Clayton [5], few residency-training programs have proposed innovations in sexual health education, since the Robert Wood Johnson Medical School (RWJMS) was developed, in 1973. Only recently, a parallel pilot model [3] was developed incorporating the three elements described in RWJMS: (i) integration of cognitive and attitudinal learning; (ii) role of a multidisciplinary team in managing sexual issues; and (iii) clinical skills, including communication skills and sexual history taking. The program was a half-day intensive workshop and enrolled 46 residents of different specialties. Most of the respondents $(92.6 \%, n=34)$ in the post-test evaluation reported that the workshop was informative and they specifically praised the live interviews and panels.

The high level of satisfaction of most of our participants may in part be attributed to the multidisciplinary lecturers. The presentation of information by different specialists was an important factor reported by the residents to help them feel more confident in dealing with their patients' sexual questions [4]. The possibility of viewing video lectures when and where they wanted is also an important advantage of online recorded courses [25]. Several of the study participants mentioned how this aspect was a strong point of the online course: "I live in Belém (north part of Brazil) and, for me, this was the only way to participate in this course. Excellent idea!" and "I loved the online format of the course and the possibility to access it from home!" However, a small number of participants were dissatisfied by the "participants' interaction" in the forums. This is a problem that has been previously reported by other investigators as one of the disadvantages of online courses [28]. In future editions of this course, we intend to establish rules of behavior for the students using the forums.

A limitation of this study was that the participants' knowledge was assessed some time after course completion. Yolsal et al. [4] sent a qualitative questionnaire four to six months after their residents had participated in a presencial course on sexuality and approximately $60 \%$ of them responded. Most of them were satisfied with the experience and valued the newly acquired knowledge [4]. In future editions of this course, we intend to ask the participants to answer a new questionnaire four months after its end, to assess their knowledge retention. Upon enrollment, the students will be informed that those who do not complete this questionnaire will not receive their final score nor receive their course completion certificate.

This study did have several strong points. Firstly, it was the largest survey to date on the training, attitudes and practices of $\mathrm{Ob} /$ Gyn residents about sexuality during pregnancy. Secondly, to the best of the authors' knowledge, this course was also the first online educational intervention specifically focused on sexuality during pregnancy. However, the course was limited to residents from 
Ob/Gyn programs in Brazil and therefore the findings cannot be generalized to other settings or countries. It is acknowledged that due to its online nature, the course did not allow the residents to fully explore their individual difficulties in dealing with their patients. An additional presencial module with individual or group tutoring would be needed to deal with these difficulties.

\section{Conclusion}

This course may serve as a model for other investigators interested in increasing the knowledge and skills of Ob/Gyn residents about sexuality during pregnancy. The course can be extended to include sexuality during the first postnatal year with a particular focus on sexuality during breastfeeding and postnatal sexual problems such as dyspareunia. This type of initiative can be especially useful in resource constrained settings and in places where presencial courses can be difficult due to geographic factors. More research is needed on how to best train $\mathrm{Ob} /$ Gyn residents in sexuality and how to best evaluate their knowledge acquisition and retention.

\section{Acknowledgments}

We would like to thank all of our colleagues who helped with their ideas and suggestions for the survey and online course: Roseli Nomura, Jorge Hosomi, Renato Santana, Luiz Kulay, Anamaria Facina, Marina Padovani e Eliana Spinelli. We thank to the professors who gave the lectures: Alessandra Diehl, Carolina Ambrogini, Denise Queiroz Ferreira, Fátima Ferreira Bortoletti, Gil Facina, Jales Clemente, Marcelo Rodrigues Cabrini, Maria Cláudia de Oliveira Lordello, Miriam Zanetti, Roney Cesar Signorini Filho and Tânia das Graças Mauadie Santana. Finally, we are grateful to Marcus Vinicius Castro for his help in analyzing the data.

\section{References}

[1] World Health Organization. Defining sexual health: report of a technical consultation on sexual health, 28-31 January, 2002 [Internet]. Geneva: WHO Press; 2006. Working definitions; [cited 2016 May 19]. p. 4-5. Available from: <http://www.who.int/reproductivehealth/publications/sexual_health/ defining_sexual_health.pdf> [chapter 3].

[2] Pan American Health Organization. World Health Organization. World Association for Sexology. Promotion sexual health of recommendations for action. In: Proceedings of a Regional Consultation; 2000 May 19-22; Antigua Guatemala, Guatemala. Washington (DC): Pan American Health Organization; 2000. Available from: <http://www1.paho.org/hq/dmdocuments/2008/ PromotionSexualHealth.pdf> [cited 2016 May 19].

[3] Rosen R, Kountz D, Post-Zwicker T, Leiblum S, Wiegel M. Sexual communication skills in residency training: the Robert Wood Johnson model. J Sex Med 2006;3(1):37-46. http://dx.doi.org/10.1111/j.17436109.2005.00135.x.

[4] Yolsal N, Karabey S, Bulut A, Topuzoglu A, Agkoc S, Onoglu N, et al. Courses for medical residents and trainers in Turkey for promotion of quality of reproductive health services: a pilot study. Reprod Health Matters 2004;12 (24):189-99.

[5] Parish SJ, Clayton AH. Sexual medicine education: review and commentary. J Sex Med 2007;4(2):259-67. http://dx.doi.org/10.1111/i.17436109.2007.00430.x.

[6] Basson R. The female sexual response: a different model. J Sex Marital Ther 2000;26(1):51-65.

[7] Pauleta JR, Pereira NM, Graca LM. Sexuality during pregnancy. J Sex Med 2010;7(1):136-42. http://dx.doi.org/10.1111/i.1743-6109.2009.01538.x.
[8] Johnson CE. Sexual health during pregnancy and the postpartum. J Sex Med 2011;8(5):1267-84. http://dx.doi.org/10.1111/j.1743-6109.2011.02223.x.

[9] Ribeiro MC, Nakamura MU, Torloni MR, Scanavino MT, do Amaral MLS, Puga MES, et al. Treatments of female sexual dysfunction symptoms during pregnancy: a systematic review of the literature. Sex Med Rev 2014;2:1-9. http://dx.doi.org/10.1002/smrj.1.

[10] Babazadeh R, Najmabadi KM, Masomi Z. Changes in sexual desire and activity during pregnancy among women in Shahroud, Iran. Int J Gynaecol Obstet 2013;120(1):82-4. http://dx.doi.org/10.1016/j.ijgo.2012.07.021.

[11] Fok WY, Chan LY, Yuen PM. Sexual behavior and activity in Chinese pregnant women. Acta Obstet Gynecol Scand 2005;84(10):934-8. http://dx.doi.org/ 10.1111/i.0001-6349.2005.00743.x.

[12] Shojaa M, Jouybari L, Sanagoo A. The sexual activity during pregnancy among a group of Iranian women. Arch Gynecol Obstet 2009;279(3):353-6. http://dx. doi.org/10.1007/s00404-008-0735-z.

[13] Trutnovsky G, Haas J, Lang U, Petru E. Women's perception of sexuality during pregnancy and after birth. Aust N Z J Obstet Gynaecol 2006;46(4):282-7. http://dx.doi.org/10.1111/j.1479-828X.2006.00592.x.

[14] Pancholy AB, Goldenhar L, Fellner AN, Crisp C, Kleeman S, Pauls R. Resident education and training in female sexuality: results of a national survey. J Sex Med 2011;8(2):361-6. http://dx.doi.org/10.1111/i.1743-6109.2010.02117.x.

[15] Vieira TC, de Souza E, da Silva I, Torloni MR, Ribeiro MC, Nakamura MU. Dealing with female sexuality: training, attitude, and practice of obstetrics and gynecology residents from a developing country. J Sex Med 2015;12 (5):1154-7. http://dx.doi.org/10.1111/ism.12875.

[16] Vieira TC, de Souza E, Abdo $\mathrm{CH}$, Torloni MR, Santana TG, Leite AP, et al. Brazilian residents' attitude and practice toward sexual health issues in pregnant patients. J Sex Med 2012;9(10):2516-24. http://dx.doi.org/10.1111/ i.1743-6109.2012.02809x.

[17] Dyer K, das Nair R. Why don't healthcare professionals talk about sex? A systematic review of recent qualitative studies conducted in the United Kingdom. J Sex Med 2013;10(11):2658-70. http://dx.doi.org/10.1111/j.17436109.2012.02856.x.

[18] Abdo C, Moreira Junior E, Santos D, Wroclawski E, Fitipaldi J. Perceptions and attitude of Brazilian physicians about erectile dysfunction: Results of the Evaluation Project] Percepções e atitudes sobre disfunção erétil entre médicos no Brasil: resultados do Projeto Avaliar. Rev Bras Med 2004;61:608. Portuguese.

[19] Parasuraman A, Zeithaml V, Berry L. SERVQUAL: a multiple-item scale for measuring consumer perceptions of service quality. Retailing: Criti Concepts 2002;64(1):140.

[20] Tureta C, Rosa A, Oliveira V. [Critical evaluation of educational services: The use of SERVQUAL model] Avaliação crítica de serviços educacionais: o emprego do modelo SERVQUAL. REGE Revista de Gestão 2007;14(4):33. Portuguese.

[21] Macedo CR, Macedo EC, Torloni MR, Atallah AN. Evaluation of a national evidence-based health care course via teleconference in a developing country. J Eval Clin Pract 2013;19(4):713-9. http://dx.doi.org/10.1111/jep.12063.

[22] Rufino AC, Madeiro A, Girao MJ. Sexuality education in Brazilian medical schools. J Sex Med 2014;11(5):1110-7. http://dx.doi.org/10.1111/ism.12476.

[23] Sidi H, Loh SF, Mahadevan R, Puteh SE, Musa R, Wong CY, et al. Knowledge and attitude on sex among medical students of a Malaysian university: a comparison study. Asia Pac Psychiatry 2013;5(Suppl 1):103-9. http://dx.doi. org/10.1111/appy.12053.

[24] Waineo E, Arfken CL, Morreale MK. Sexual health education: a psychiatric resident's perspective. Acad Psychiatry 2010;34(5):357-60. http://dx.doi.org/ 10.1176/appi.ap.34.5.357.

[25] Chapman C, White CB, Engleberg C, Fantone JC, Cinti SK. Developing a fully online course for senior medical students. Med Educ Online 2011;16:5733. http://dx.doi.org/10.3402/meo.v16i0.5733.

[26] Afshar M, Mohammad-Alizadeh-Charandabi S, Merghti-Khoei E-S, Yavarikia P. The effect of sex education on the sexual function of women in the first half of pregnancy: a randomized controlled trial. J Caring Sci 2012;1(4):173-81.

[27] Shindel AW, Parish SJ. Sexuality education in North American medical schools: current status and future directions. J Sex Med 2013;10(1):3-17. http://dx.doi. org/10.1111/j.1743-6109.2012.02987.x.

[28] Tolentino RSS, Gonçalves Filho C, Tolentino RJV, Monteiro PRR. [Evaluation of quality in distance education from the student's perspective: proposition and test of a model using structural equations] Avaliação da qualidade na educação a distância sob a perspectiva do aluno: proposição e teste de um modelo usando equações estruturais. REGE Revista de Gestão 2013;20(3):347-66. Portuguese. 